\title{
Rumah, Tempat Kembali: Pemaknaan Rumah pada Mahasiswa Rantau
}

\author{
Clement Eko Prasetio ${ }^{(1)}$, Esther Gustara Nadine Sirait ${ }^{(2)}$, Aulia Hanafitri ${ }^{(3)}$ \\ ${ }^{(1),(2),(3)}$ Fakultas Psikologi, Universitas Padjadjaran, Jatinangor, Indonesia
}

\begin{abstract}
Regional students (Indonesian: Mahasiswa rantau) are individuals who should move away from home to study in other cities, who are highly likely to experience feelings of homesickness. In this research, we aimed to understand what causes regional students' homesickness and what the meanings of home for them are. Participants in this research were 15 regional students from the Faculty of Psychology, Padjadjaran University, who were recruited through convenience sampling. This research was designed as a qualitative study with a phenomenological approach. Data in this research, which were drawn from in-depth interviews, revealed eight themes related to regional students' homesickness. These themes included feelings, activities, routines, food, pets, family and friends, home atmosphere, and rooms. Additional findings uncovered two meanings of homesickness for regional students, that is, "home is feelings" and "home is family". Empirical findings in this research provide a useful insight into the prevention of regional students' homesickness, by focusing on the meanings of home and efforts to provide new environment for those students.
\end{abstract}

Keywords: meanings of home, regional students, qualitative study

Mahasiswa rantau merupakan individu yang harus meninggalkan daerah asal untuk menuntut ilmu di kota lain, yang sangat mungkin mengalami perasaan rindu rumah atau homesickness. Penelitian ini bertujuan untuk memahami berbagai hal sebagai sumber homesickness dan makna rumah bagi mahasiswa rantau. Subjek penelitian adalah 15 mahasiswa rantau Fakultas Psikologi Universitas Padjadjaran, yang direkrut melalui convenience sampling. Penelitian menggunakan metode kualitatif dengan pendekatan fenomenologi. Hasil penelitian atas dasar wawancara mendalam dengan subjek penelitian menemukan delapan tema yang terkait dengan homesickness mahasiswa rantau, yaitu perasaan, aktivitas, rutinitas, makanan, hewan peliharaan, keluarga dan teman, suasana rumah, serta kamar. Temuan lain mengungkap dua makna rumah bagi mahasiswa rantau, yaitu "rumah adalah perasaan" dan "rumah adalah keluarga". Hasil penelitian ini dapat digunakan sebagai acuan untuk pencegahan homesickness pada mahasiswa rantau, dengan fokus pada makna rumah bagi mereka dan upaya menyediakan lingkungan baru mereka.

Kata kunci: mahasiswa rantau, makna rumah, studi kualitatif

MEDIAPSI, 2020, Vol. 6(2), 132-144, DOI: https://doi.org/10.21776/ub.mps.2020.006.02.7

Received: 10-07-2020. Revised: 28-09-2020. Accepted: 18-10-2020. Published online: 07-12-2020

Handling Editor: Intan Rahmawati, Universitas Brawijaya, Malang, Indonesia

*Corresponding author: Clement Eko Prasetio, Fakultas Psikologi, Universitas Padjadjaran, Jatinangor, Indonesia.

E-mail: clement17001@mail.unpad.ac.id

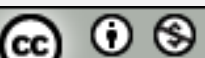

This work is licensed under a Creative Commons Attribution-NonCommercial 4.0 International License.

How to cite this article in accordance with the American Psychological Association (APA) $6^{\text {th }}$ guidelines:

Prasetio, C. E., Sirait. E. G. N., \& Hanafitri, A. (2020). Rumah, tempat kembali: Pemaknaan rumah pada mahasiswa rantau. MEDIAPSI, 6(2), 132-144. https://doi.org/10.21776/ub.mps.2020.006.02.7

\section{Pendahuluan}

Mahasiswa yang merantau dapat didefinisikan sebagai individu yang menetap dan menuntut ilmu di daerah lain sebagai persiapan untuk mencapai suatu keahlian pada jenjang perguruan tinggi (Lingga \& Tuapattinaja, 2012). Tujuan merantau pada mahasiswa umumnya adalah meraih kesuksesan 
melalui kualitas pendidikan yang lebih baik dan membuktikan kualitas diri sebagai orang dewasa yang mandiri dan bertanggung jawab (Santrock, 2016).

Fenomena mahasiswa yang merantau di Indonesia cukup umum. Berdasarkan data Kementerian Riset Teknologi dan Pendidikan Tinggi ("Menristekdikti umumkan klasterisasi perguruan tinggi Indonesia 2019, fokuskan hasil dari perguruan tinggi”, 2019), biasanya mahasiswa akan cenderung merantau ke pulau Jawa, karena banyaknya universitas yang memiliki akreditasi tinggi di Pulau Jawa, seperti Institut Teknologi Bandung, Institut Pertanian Bogor, Institut Teknologi Surabaya, Universitas Indonesia, Universitas Diponegoro, Universitas Airlangga, Universitas Gadjah Mada, Universitas Padjadjaran, dan Universitas Brawijaya. Hal tersebut sesuai dengan data yang berasal dari Badan Akreditas Nasional Perguruan Tinggi (BAN-PT), yang menunjukkan bahwa pada tahun 2020, sebagian besar universitas/akademi/institut yang terakreditasi A berada di pulau Jawa (Adit, 2020). Mengacu pada data tersebut, tidak mengherankan jika mahasiswa meninggalkan daerah mereka dan merantau ke kota tempat perguruan tinggi tersebut berada, untuk mendapatkan pendidikan yang lebih baik.

Menurut salah satu laman berita, yaitu AntaraRiau ("Mahasiswa asal Riau Terbanyak kedua di Yogyakarta", 2014), terdapat sekitar 18 ribu mahasiswa asal Sumatera Utara, 14 ribu mahasiswa asal Riau, dan 12 ribu mahasiswa asal Nusa Tenggara yang berkuliah di Yogyakarta. Angka tersebut menunjukkan bahwa cukup banyak mahasiswa yang merantau ke pulau Jawa untuk berkuliah. Berdasarkan data dari Universitas Padjadjaran ("Statistik Universitas Padjadjaran September 2016", 2016), ditemukan jumlah tertinggi mahasiswa baru Universitas Padjadjaran berasal dari Jawa Barat, yakni 4591 orang. Mahasiswa tersebut berasal dari berbagai kota di Jawa Barat, seperti Bekasi, Tasikmalaya, Bogor, Sukabumi, dan lain sebagainya. Meski berasal dari Jawa Barat, mereka juga harus melakukan "perantauan" karena letak Universitas Padjadjaran yang berada di Sumedang. Kemudian, ada juga mahasiswa baru yang berasal dari luar pulau Jawa, seperti dari Sumatera Barat dengan jumlah 308 orang, Sumatera Utara berjumlah 215, dan dari berbagai pulau lainnya di Indonesia ("Statistik Universitas Padjadjaran September 2016”, 2016).

Saat merantau, mahasiswa tentu akan meninggalkan rumah dan berpisah dari keluarga, teman-teman, kerabat, serta hal lain yang berada di tempat asalnya. Di perantauan, mereka mungkin menemukan hal-hal baru yang tidak pernah mereka alami di kota atau tempat asal mereka. Perpisahan tersebut dapat menimbulkan sejumlah perasaan seperti kesedihan, kecemasan, putus asa, ataupun nostalgia (Azizi, 2015; Compton \& Hoffman, 2013; Scharp, Paxman, \& Thomas, 2015). Selain itu, perasaan lain yang mungkin dirasakan adalah perasaan rindu rumah atau homesickness (Azizi, 2015).

Homesickness merupakan perasaan dan fenomena yang menyerupai perasaan berduka ketika individu ditinggalkan oleh orang yang dikasihinya (Stroebe, Schut, \& Nauta, 2015, 2016). Dalam cakupan yang lebih luas, mahasiswa internasional (international students) misalnya merasakan homesickness lebih kuat dibandingkan dengan mahasiswa yang tidak merantau atau mahasiswa domestik (Poyrazli \& Lopez, 2007). Hal tersebut terjadi karena saat merantau terjadi perpisahan antara individu dengan suatu hal, dalam hal ini adalah rumahnya. Meskipun begitu, homesickness yang berkepanjangan dapat menimbulkan dampak-dampak yang buruk, seperti kesepian, isolasi sosial, depresi, masalah ingatan, penurunan imun tubuh, atau bahkan diabetes (Thurber \& Walton, 2012). Bahkan, homesickness dapat menimbulkan berbagai gangguan klinis seperti adjustment disorder ataupun separation anxiety disorder. Adjustment disorder terjadi ketika seseorang terpapar stressor, kemudian mengalami gejala- 
gejala seperti stres dan mengalami kesulitan dalam bersosialisasi, bekerja, atau melakukan aktivitas-aktivitas penting dalam hidupnya (American Psychiatric Association, 2013; Stroebe dkk., 2016). Gejala-gejala tersebut muncul dengan durasi 3-6 bulan sejak munculnya sumber stres. Separation anxiety disorder juga dapat terjadi ketika seseorang berpisah dari rumah atau dengan orang yang dicintainya. Separation anxiety disorder biasanya terjadi dalam waktu enam bulan atau lebih. Gejala yang dirasakan seperti adanya perasaan cemas mengenai figur atau orang tertentu, kemudian perasaan stres ketika mengantisipasi atau mengalami perpisahan dari rumah atau orang yang dicintai, dan sebagainya (American Psychiatric Association, 2013).

Berdasarkan dampak negatif dari homesickness yang dapat dialami oleh mahasiswa rantau, penting bagi seseorang untuk mengetahui hal-hal yang mereka rindukan dari rumah dan makna rumah secara keseluruhan sebagai seorang mahasiswa perantau. Hal tersebut sesuai dengan pernyataan Vingerhoets (2005) bahwa pengetahuan seseorang mengenai hal-hal yang dirindukan dari rumah dan mengenai makna rumah secara keseluruhan (gestalt) mendorong upaya seseorang tersebut untuk mengatasi kerinduan pada rumah. Selain itu, mengetahui makna rumah secara keseluruhan juga berimplikasi pada pencarian dukungan sosial yang dapat membantu individu untuk beradaptasi dengan lingkungan baru dan mengurangi perasaan rindu rumah (Scharp dkk., 2015).

Berdasarkan penjelasan yang sudah dipaparkan sebelumnya mengenai homesickness dan berbagai macam dampaknya, dapat diketahui bahwa penelitian mengenai hal yang dirindukan dari rumah dan makna rumah telah dilakukan di luar negeri, khususnya di Eropa, dengan subjek mahasiswa yang mengalami homesickness (Scharp dkk., 2015). Di Indonesia, studi serupa juga telah dilakukan oleh beberapa peneliti, yang menngaitkan homesickness mahasiswa rantau dengan dukungan sosial dan attachment (Istanto \& Engry, 2019; Lumawo, 2007).

Meski demikian, penelitian mengenai pemaknaan rumah dan hal yang dirindukan dari rumah belum pernah dilakukan di Indonesia. Menimbang pentingnya pemahaman mengenai pemaknaan dari fenomena homesickness pada mahasiswa rantau dalam mengatasi kerinduan terhadap rumah asal dan minimnya penelitian terkait hal tersebut di Indonesia, penelitian ini bertujuan untuk memahami hal-hal yang dirindukan dari rumah dan makna rumah bagi mahasiswa yang merantau.

\section{Metode}

\section{Partisipan dan desain penelitian}

Jumlah partisipan dalam penelitian ini adalah 15 mahasiswa sarjana Fakultas Psikologi Universitas Padjadjaran angkatan 2017-2019 yang merantau dan tinggal di kos, asrama, atau kontrakan. Setiap angkatan terdiri dari lima mahasiswa, dengan rata-rata usia 18.5 tahun. Partisipan berasal dari berbagai daerah, yaitu DKI Jakarta, Jawa Barat, Jawa Tengah, DI Yogyakarta, Bali, Kalimantan Timur, Sulawesi Selatan, Riau, Sumatera Utara, Papua, dan Aceh. Penentuan partisipan menggunakan convenience sampling sebagai salah satu teknik non-random sampling yang menekankan kemudahan peneliti untuk menjangkau partisipan dan juga keinginan partisipan untuk berpartisipasi (Robinson, 2014).

Penelitian ini dirancang sebagai studi kualitatif dengan pendekatan fenomenologi. Fokus pada penelitian ini adalah mendeskripsikan hal-hal yang dirindukan dari rumah dan makna rumah bagi mahasiswa Fakultas Psikologi Universitas Padjajaran yang merantau (Creswell \& Poth, 2018).

\section{Prosedur penelitian}

Metode pengumpulan data yang digunakan adalah wawancara mendalam atau in-depth interview. Dalam wawancara ini, pertanyaan utama yang diajukan adalah "Hal apa yang dirindukan dari rumah?” dan "Apa makna rumah bagi Anda?". Berdasarkan dua 
pertanyaan utama tersebut, peneliti melakukan inquiry lebih lanjut mengenai alasan-alasan mahasiswa merindukan hal tersebut dan proses yang terjadi pada diri mahasiswa sehingga muncul pemaknaan tertentu terkait rumah (Creswell \& Poth, 2018).

Teknik yang digunakan untuk menganalisis data penelitian ini adalah thematic analysis, dengan pendekatan data-driven. Datadriven berarti mengidentifikasi kemiripan semua tema yang muncul yang berasal dari jawaban-jawaban partisipan. Terdapat enam tahapan yang dilakukan dalam thematicanalysis. Tahap pertama adalah membaca dan mengenal data yang telah didapatkan, sementara tahap kedua adalah menemukan kode-kode awal dari data yang tersedia. Tahap ketiga adalah mencari tema-tema, yang diikuti dengan langkah keempat, yaitu melakukan peninjauan dan penelaahan tema-tema yang potensial. Langkah kelima adalah mendefinisikan dan memberikan nama pada tema-tema yang diperoleh, sementara langkah keenam sekaligus terakhir adalah membuat laporan tertulis mengenai temuan (Braun \& Clarke, 2006).

Berdasarkan enam tahapan tersebut, kedua peneliti yang terlibat dalam pengolahan data terlebih dahulu membuat transkrip wawancara secara manual berdasarkan rekaman wawancara dengan partisipan. Kemudian, masing-masing peneliti membaca keseluruhan transkrip wawancara tersebut dan mengenal serta menghayati pengalaman partisipan. Setelah membaca transkrip tersebut, masingmasing peneliti memberikan kode secara manual terhadap seluruh jawaban partisipan. Kedua peneliti kemudian mencari tema dari hasil koding yang telah diperoleh secara independen, dengan tema yang dicari berupa hal-hal yang dirindukan dari rumah serta pemaknaan partisipan terhadap rumah. Setelah kedua peneliti memperoleh tema-tema tersebut, dilakukan diskusi hasil temuan masing-masing dan memutuskan tema yang paling tepat dalam menggambarkan pengalaman partisipan. Tema- tema yang telah diputuskan tersebut kemudian didefinisikan oleh kedua peneliti secara bersama-sama. Aspek credibility dalam penelitian ini diperoleh melalui metode member checking (Creswell \& Creswell, 2018). Dengan metode member checking ini, peneliti mengirimkan kembali hasil pengolahan data yang telah dibuat, berupa tema-tema dan definisi kepada para partisipan. Proses selanjutnya adalah meminta pendapat dari para partisipan mengenai tema-tema yang dihasilkan. Jika para partisipan memiliki hal yang ingin ditambahkan atau diklarifikasi, maka jawaban dicatat dan dilakukan pengolahan data kembali. Pada penelitian ini, partisipan menyetujui semua temuan peneliti dan tidak memiliki tambahan terkait hal yang harus didiskusikan. Sementara itu, untuk menjamin aspek trustworthiness, peneliti membaca terlebih dahulu transkrip dan mengolah data secara independen. Kemudian, peneliti melakukan diskusi untuk mendapatkan hasil akhir. Setelah itu, peneliti membaca kembali keseluruhan transkrip yang telah dibuat untuk memastikan tidak adanya kesalahan dalam proses transkripsi (Creswell \& Creswell, 2018).

\section{Hasil}

Berdasarkan pengolahan hasil wawancara dengan menggunakan pendekatan data-driven, tema-tema mengenai hal yang dirindukan dari rumah dan makna rumah, serta contoh tanggapan terhadap masing-masing tema ditampilkan dalam Tabel 1 di halaman berikut.

Sementara itu, makna rumah bagi mahasiswa rantau diuraikan sebagai berikut:

1. Perasaan. Partisipan menceritakan perasaannya ketika ia di rumah, seperti "Ya, menurut aku rumah itu, tempat untuk kembali gitu” (AS19). Terdapat juga partisipan yang menggambarkannya dengan jelas, seperti "ya, makna rumah buatku, sama yang kayak hal apa yang dirindukan dari rumah, yaitu suasana nyaman sih. Jadi, selama ada suasana yang nyaman buat aku, itu sudah cukup 
jadi rumah buat aku. Aku gak harus pulang ke rumahku di tempat asal. Yang penting, aku merasa nyaman" (II8).

Tabel 1. Hal-Hal yang Dirindukan oleh Mahasiswa Rantau dari Rumah

\begin{tabular}{|c|c|c|}
\hline $\begin{array}{l}\text { Hal yang } \\
\text { dirindukan }\end{array}$ & Definisi & Contoh jawaban \\
\hline Perasaan & $\begin{array}{l}\text { Hal yang meliputi } \\
\text { emosi dan pengalaman } \\
\text { psikologis }\end{array}$ & $\begin{array}{l}\text { "aku kangen dengan keceriaan di } \\
\text { dalam rumah." (K10) atau "yang } \\
\text { membuat kangen adalah } \\
\text { kenyamanannya gitu" (Z5) }\end{array}$ \\
\hline Aktivitas & $\begin{array}{l}\text { Hal yang dilakukan } \\
\text { bersama orang-orang di } \\
\text { rumah atau tempat asal. }\end{array}$ & $\begin{array}{l}\text { "biasanya aku jalan-jalan bareng } \\
\text { keluarga, lalu sambil jalan-jalan } \\
\text { juga cerita-cerita, bercanda } \\
\text { bareng" (DA14) }\end{array}$ \\
\hline Rutinitas & $\begin{array}{l}\text { Hal yang dilakukan } \\
\text { secara rutin di rumah }\end{array}$ & $\begin{array}{l}\text { "ya aku kangen dengan kegiatan } \\
\text { aku di rumah, kayak nyapu, nyuci, } \\
\text { nyuci mobil" (AS12) }\end{array}$ \\
\hline Makanan & $\begin{array}{l}\text { Hal yang berhubungan } \\
\text { dengan makanan, } \\
\text { berupa makanan khas } \\
\text { daerah, makanan yang } \\
\text { dimasak di rumah, dan } \\
\text { makanan yang biasa } \\
\text { dinikmati dalam } \\
\text { suasana rumah }\end{array}$ & $\begin{array}{l}\text { "kangen banget sama } \\
\text { makanannya, karena kaya } \\
\text { rempah, ada jahe dan lain-lain..." } \\
(F 12)\end{array}$ \\
\hline $\begin{array}{l}\text { Hewan } \\
\text { peliharaan }\end{array}$ & $\begin{array}{l}\text { Hewan yang dipelihara } \\
\text { di rumah }\end{array}$ & $\begin{array}{l}\text { “... ada kucing yang selalu aku } \\
\text { rawat. Aku elus-elus dan ajak } \\
\text { ngobrol ketika di rumah” (RI2) }\end{array}$ \\
\hline $\begin{array}{l}\text { Keluaga dan } \\
\text { teman }\end{array}$ & $\begin{array}{l}\text { Orang-orang yang } \\
\text { dianggap sebagai } \\
\text { keluarga dan teman }\end{array}$ & $\begin{array}{l}\text { "yaa, kangen sama keluarga, } \\
\text { terus sama teman-teman juga", } \\
\text { (S10) }\end{array}$ \\
\hline $\begin{array}{l}\text { Suasana } \\
\text { rumah }\end{array}$ & $\begin{array}{l}\text { Hal-hal yang } \\
\text { menyangkut kondisi di } \\
\text { lingkungan sekitar } \\
\text { rumah }\end{array}$ & $\begin{array}{l}\text { “... yang aku rindu dari rumah, } \\
\text { tuh, seperti baunya. Terus, aku } \\
\text { kangen juga dengan suara yang } \\
\text { agak bising di rumah.” (J8) }\end{array}$ \\
\hline Kamar & $\begin{array}{l}\text { Hal yang melibatkan } \\
\text { kebiasaan dan suasana } \\
\text { di dalam kamar }\end{array}$ & $\begin{array}{l}\text { "Keadaan dan suasana kamarku. } \\
\text { Karena di kamar itu, jadi tempat } \\
\text { aku mengerjakan tugas, tempat } \\
\text { aku menenangkan diri. Di kamar } \\
\text { itu, istilahnya udah lama gitu. } \\
\text { Udah lama gitu, aku tinggal di } \\
\text { sana juga." (AS8) }\end{array}$ \\
\hline
\end{tabular}

2. Selain itu, ditemukan juga partisipan yang menjelaskan dengan lebih spesifik, bahwa rumah merupakan tempat yang nyaman dan aman untuknya karena ia dapat menjadi dirinya sendiri. Jawabannya seperti berikut "Ya.. Makna rumah buatku adalah aku sendiri sih. Di rumah, aku bebas jadi diri apa adanya. Karena yakin, orang tua dan keluargaku pasti menerima aku apa adanya. Kalau disini, harus agak jaga image” (TA20). Kemudian, ada juga yang menyatakan bentuk perasaan aman dan nyaman berkaitan dengan pemenuhan berbagai bentuk kebutuhan. Jawabannya seperti "Jadi hal yang membuat aku memaknakan rumah adalah karena support system aku gitu. Karena memenuhi kebutuhan fisiologis aku, terus memenuhi kebutuhanku untuk sharing, dan untuk memenuhi kebutuhan untuk dewasa" (R28).

3. Keluarga. Partisipan menceritakan mengenai orang-orang (keluarga) yang ditemui di rumah. Partisipan memaknai rumah sebagai orang-orang rumah yang bermakna berada di dekatnya. Ia menjelaskan seperti ini “... Waktu itu juga adik aku pernah ngunjungin ke sini, aku ngerasa itu rumah aku gitu. Ketika aku bertemu sama orang orang yang aku sayang, itu rumah." (I20). Selain itu, partisipan juga menyatakan bahwa baginya, rumah dimaknakan sebagai bangunan fisik untuk berinteraksi dengan orang-orang di dalamnya. Hal tersebut ditunjukkan melalui pernyataan salah satu partisipan, yaitu "Jadi harus ada rumah fisik, dan ada interaksi dengan keluarga di dalamnya, itu baru rumah buat aku. Baik interaksi aku sendiri dengan mereka maupun interaksi orang orang di dalamnya" (J22).

\section{Diskusi}

\section{Hal yang dirindukan dari Rumah}

Hasil penelitian ini menemukan delapan hal yang dirindukan oleh mahasiswa rantau dari rumah mereka, yaitu perasaan, aktivitas (merujuk pada aktivitas bersama keluarga atau orang-orang di lingkungan rumah), rutinitas, makanan, hewan peliharaan, keluarga dan teman, suasana rumah, serta kamar mereka.

Keluarga dan teman menjadi salah satu hal yang dirindukan oleh partisipan. Kerinduan pada keluarga dan teman ternyata merupakan hal yang umum terjadi (Stroebe dkk., 2002; Nijhof \& Engels, 2007). Hal ini dapat terjadi 
karena mahasiswa sudah membentuk ikatan dan membentuk attachment (kelekatan) dengan keluarga dan teman-teman yang ada di lingkungan tempat asalnya (Shaver \& Mikulincer, 2007). Attachment dapat terjadi karena adanya interaksi yang terus menerus antara mahasiswa dengan keluarga dan temantemannya (Ainsworth, Blehar, Waters, \& Wall, 1978; Bowlby, 1982). Attachment pada keluarga terbentuk sejak individu dilahirkan. Kemudian, ketika mulai bertumbuh dewasa, individu pun juga akan mulai berinteraksi dengan orang-orang di luar rumahnya (secara khusus, bertemu dengan teman-teman sebayanya) sehingga membentuk attachment tersendiri (Santrock, 2020). Attachment dengan orang lain tentunya akan membuat individu merasa aman dan nyaman (Ainsworth dkk., 1978; Santrock, 2020). Selain perasaan aman dan nyaman, adanya kelekatan dengan keluarga dan teman, juga membentuk ingatan atau memori spesifik pada pikiran masing-masing mahasiswa (Scannel \& Gifford, 2010). Adanya perasaan aman yang dirasakan dan adanya memori tertentu dengan keluarga dan teman di tempat asal membuat mahasiswa rantau merindukan keluarga dan teman-teman.

Sementara itu, aktivitas yang dirindukan dari rumah adalah aktivitas yang dilakukan oleh orang-orang di rumah, baik itu keluarga maupun teman. Terkait dengan rutinitas, partisipan mengemukakan bahwa mereka merindukan aktivitas bersama keluarga karena melalui aktivitas tersebut, mereka dapat menjadi semakin dekat dengan keluarga mereka. Hal ini sejalan dengan teori interpersonal attachment. Interpersonal attachment theory mengemukakan bahwa semakin banyak interaksi yang timbul antara anak dengan orang tua (atau antara dua orang), maka mereka akan semakin membangun kelekatan dan kedekatan (Ainsworth dkk., 1978; Bowlby, 1982). Adanya aktivitas rutin yang dilakukan bersama anggota keluarga juga memiliki peran penting dalam kondisi kesehatan mental anak di dalam keluarga (Feist
\& Feist, 2009). Ketika merantau, mahasiswa tidak dapat melakukan aktivitas bersama keluarga, yang membuat mereka merindukan aktivitas tersebut. Selain itu, menurut Archer, Ireland, Amos, Board, dan Currid (1998), hilangnya rutinitas atau kebiasaan yang dilakukan di rumah juga dapat membuat individu merasakan homesick atau rindu rumah. Hal ini dapat terjadi karena adanya rutinitas yang sudah biasa dilakukan dapat membantu individu untuk lebih efektif dalam memanfaatkan sumber daya yang dimiliki terkait pemecahan masalah dan kegiatankegiatan kognitif, emosional, maupun perilaku lainnya (Dunn, 2000). Ketika meninggalkan rumah dan rutinitas yang dimiliki, mahasiswa merindukan hal tersebut dan merasa harus melakukan lebih banyak hal di tempat barunya. Sebagai contoh, salah satu partisipan mengatakan: "Paling kalo di rumah ya lebih santai gitu tempatnya daripada pas kuliah" (W11).

Hal yang lain yang dirindukan dari rumah adalah makanan. Terdapat partisipan yang menyatakan bahwa "aku kangen dengan makanan rumah, karena kalau di rumah bisa makan sepuasnya dan bisa nambah" (W9) dan "Kangen banget sama makanannya, karena kaya rempah, ada jahe dan lain-lain..." (F12). Partisipan lainnya juga menyatakan "kan makanannya mungkin sama tapi karena beda yang masak, rasanya juga jadi beda" (CT10). Berdasarkan teori place attachment, individu dapat mengalami perasaan rindu karena memiliki kelekatan dengan rumah atau tempat tinggalnya, sebagai hasil dari peran dimensi person dan process, yang menghasilkan ingatan atau pemaknaan khusus mengenai makanan di rumahnya (Scannell \& Gifford, 2010). Pemaknaan khusus mengenai makanan dan perasaan yang terkait mempengaruhi penilaian mahasiswa terhadap makanan di perantauannya yang dianggap berbeda dengan di rumah (Johnson, Kim, \& Risse, 1985). Selain itu, penelitian lain juga mengungkapkan bahwa individu dapat merindukan makanan karena di 
dalamnya terkandung nilai-nilai budaya tertentu yang mempengaruhi preferensinya (PinaConcas dkk., 2019). Individu juga lebih senang dengan apa yang sudah sering dikonsumsi, yang akhirnya menghasilkan kebiasaan tertentu (Wądołowska, Babicz-Zielińska, \& Czarnocińskac, 2008). Dengan kata lain, ketika mahasiswa rindu dengan makanan, dapat diindikasikan bahwa ia pun merindukan kebiasaan yang biasa dijalankan selama berada di tempat asalnya.

Kamar dapat menjadi hal yang dirindukan oleh mahasiswa. Kerinduan terhadap kamar tersebut dapat dijelaskan menggunakan teori place attachment. Pada dimensi process dari place attachment tersebut, terjadi berbagai kegiatan di dalam kamar, yang ditunjukkan melalui pernyataan "aku rindu kamar sih. Karena biasanya aku banyak melakukan aktivitasku di sana" (F16). Selain itu, pada dimensi person, terjadi pemaknaan kamar yang bersifat pribadi pada individu (Scannell \& Gifford, 2010). Pemaknaan tersebut dapat terjadi melalui ingatan tentang kenangan masa lalu dan interaksi sosial yang terjadi di dalam kamar (Fidzani \& Read, 2012). Menggambarkan hal ini, partisipan menyatakan kerinduannya pada kamarnya karena "itu kamar aku dari kecil jadi sudah terbiasa dan aku merasa nyaman aja di situ. Kalau misalnya di kuliah itu kan kamar itu kaya cuman untuk tidur, kalo kamar aku yang di sana untuk main, ngobrol sama adek aku” (S15). Kamar juga dapat menjadi bagian spesifik dari rumah yang dirindukan karena kamar umumnya menjadi ruang pertama bagi individu dimana mereka memiliki kontrol dan kepemilikan penuh di dalamnya dan merupakan ruang yang memberikan perasaan keleluasaan pribadi (Lincoln, 2015). Perasaan terhadap keleluasaan pribadi membuat individu merindukan kamar di rumah yang dapat menjadi tempat mereka beristirahat dan menenangkan diri dari permasalahan yang dihadapi.

Hewan peliharaan juga menjadi hal yang dirindukan oleh partisipan. Temuan penelitian ini juga sejalan dengan temuan dari beberapa penelitian sebelumnya (Scharp dkk., 2015; Thurber dkk., 2007) yang mengungkap bahwa hewan peliharaan juga bisa menjadi hal yang dirindukan dari rumah. Hewan peliharaan mungkin menjadi hal yang mendorong individu rindu dengan rumah, karena aktivitas yang dilakukan bersama dengan hewan peliharaan juga membuat individu memiliki ikatan khusus dengan hewan peliharaan tersebut (Hawkins \& Williams, 2017). Ikatan dengan hewan peliharaan ini dapat membuat individu merasa tenang dan nyaman. Hal ini sesuai dengan pernyataan salah satu partisipan yang sangat rindu dengan kucingnya, yaitu "Hal yang bikin aku kangen rumah, karena ada kucingkucingku. Jadi, kalau di rumah aku sering banget ngobrol sama kucing-kucingku gitu ka. Jadi, aku gak kesepian dan happy ka. Nah sekarang kan udah gak bisa, jadi ya kayak sepi gitu ka." (R10). Ketika merasakan adanya ikatan yang hilang, mahasiswa tersebut merasa ada yang hilang dari dirinya dan hal ini lah yang menimbulkan perasaan rindu terhadap rumah.

Partisipan juga menyebutkan bahwa perasaan menjadi hal yang membuat mereka rindu dengan rumah mereka. Perasaan yang dimaksud adalah perasaan yang positif dan mengesankan ketika berada di rumah, seperti keceriaan dan kenyamanan. Temuan penelitian ini juga ditemukan dalam penelitian lain seperti penelitian Scharp dkk. (2015) dan juga penelitian Thurber dkk. (2007). Penelitianpenelitian tersebut menemukan bahwa perasaan aman, nyaman, dan positif membuat individu merindukan rumahnya. Perasaan nyaman itu menjadi hal yang cukup dirindukan karena menjadi salah satu kebutuhan manusia (Maslow, 1968 dalam Feist \& Feist, 2009). Perasaan tersebut bisa terbentuk karena adanya interaksi yang aktif antara partisipan dengan figur yang ada di rumah (Blumer, 1986). Adanya kelekatan atau attachment yang memunculkan perasaan nyaman dan ceria 
tersebut terbentuk dalam diri partisipan ketika berada di rumah.

Berbagai hal yang dirindukan oleh partisipan (mahasiswa) terhadap rumah selalu muncul dari adanya interaksi dan adanya kelekatan tertentu dengan figur di rumah (interpersonal attachment), atau bahkan dari kelekatan dengan rumah sebagai suatu tempat (place attachment). Kelekatan-kelekatan ini membuat individu mendapatkan berbagai perasaan aman dan nyaman. Konsekuensinya, ketika mereka harus berpisah dari sumber rasa aman, nyaman, atau ceria partisipan akan merasa rindu dengan hal-hal tersebut.

\section{Makna Rumah}

Penelitian ini juga menemukan dua makna, yakni rumah sebagai perasaan serta rumah sebagai orang. Makna rumah sebagai perasaan mengandung arti rumah sebagai kumpulan perasaan positif (aman dan nyaman), seperti "hmm ... iya. Kayak merasa nyaman aja gitu ka. Jadi kalau ada masalah pulang gitu ke rumah. Jadi, ya tempat pulang, karena merasa nyaman gitu ka. Ya, disana kan ada juga keluarga aku, terus temen aku juga. Jadi, ya merasa nyaman dan aman gitu aja ka hehe." (Z18). Menurut Bowlby (1982), individu akan membangun attachment dengan figur yang memiliki peran besar dalam merawatnya dan orang-orang di dalam rumah. Attachment yang kuat antara mahasiswa dengan anggota keluarganya memunculkan perasaan aman dan nyaman ketika interaksi tersebut terjadi.

Perasaan aman dan nyaman juga bisa terbentuk pada diri individu, yang bermuara pada adanya kebutuhan-kebutuhan individu yang terpenuhi dalam keluarga. Menurut teori hierarchy of needs dari Maslow (Feist \& Feist, 2009), individu akan cenderung untuk memenuhi semua kebutuhan dasarnya agar bisa mencapai aktualisasi diri. Pemaknaan mengenai rasa aman dan nyaman bisa terbentuk juga karena adanya dorongan untuk terus memenuhi kebutuhan. Salah satu partisipan menyebutkan bahwa ketika berada di rumah, ia mendapatkan kebutuhan secara fisiologis, kebutuhan untuk bisa sharing dengan orang lain, dan kebutuhan untuk bertumbuh dewasa dan mengerti orang lain. Ketika semua kebutuhan tersebut terpenuhi, ia akan merasa aman dan tidak merasa kekurangan apapun. Kebutuhan ini bisa terpenuhi di rumah karena adanya interaksi yang aktif antara individu dengan figur-figur di rumah (Blumer, 1986).

Rumah sebagai perasaan tidak hanya digambarkan sebagai adanya kelekatan dengan figur tertentu. Rumah sebagai perasaan juga bisa digambarkan sebagai adanya kelekatan dengan rumah serta adanya interaksi di dalamnya yang bisa menimbulkan perasaan nyaman dan aman. Salah satu partisipan menyatakan "Kadang aku suka pulang ke rumah nenekku di Purwakarta. Tapi rasanya beda gitu. Perasaan amannya tidak sepenuh kalau di Yogyakarta. Ya mungkin karena di Yogya sudah dari kecil, terus juga sudah banyak hal yang dilakukan disana, jadi merasa lebih nyaman aja." (AS23). Kumpulan perasaan yang positif sebagai makna rumah juga dapat dijelaskan dengan konsep place attachment, terutama dimensi process. Pada dimensi tersebut, mahasiswa membentuk ikatan dengan rumah karena adanya proses afektif dan kognitif di dalamnya (Scannell \& Gifford, 2010).

Pemaknaan rumah sebagai perasaan juga tergambar dari jawaban partisipan yang menekankan bahwa di rumah mereka bisa lebih apa adanya. Berdasarkan jawaban partisipan, seperti "aku bisa menjadi diriku yang sebenarnya. Tidak perlu menjaga image gitu. Aku yakin orang tuaku pasti menerimaku seutuhnya. Kalau disini (tempat kuliah) harus menjaga image. Kayak harus dandan dulu kalau mau keluar. Kalau dirumah kan, tinggal langsung keluar aja." (TA27) menunjukkan adanya pemaknaan bahwa rumah dapat membuat dirinya lebih bebas. Perasaan bebas menjadi diri sendiri tersebut dapat dijelaskan karena adanya interaksi antara mahasiswa dengan orang tua, serta dengan lingkungan di kampus. Menurut Blumer (1986), makna 
seseorang mengenai suatu hal terbentuk dan juga dapat berubah atau dimodifikasi karena adanya interaksi dengan lingkungan di sekitar. Mahasiswa pada awalnya berinteraksi dengan keluarganya dan membentuk suatu makna bahwa rumah merupakan tempat yang aman. Kemudian, pemaknaan rumah sebagai tempat yang aman difokuskan lagi pada tempat untuk dapat merealisasikan diri dengan seutuhnya, tanpa harus menjaga "image diri" ataupun takut tidak diterima. Pemaknaan sebagai tempat merealisasikan diri atau menampilkan diri yang sebenar-benarnya merupakan pemaknaan yang tidak didapatkan ketika mahasiswa merantau dan berinteraksi dengan lingkungannya (lingkungan kampus ataupun lingkungan tempat tinggal yang baru). Pemaknaan mengenai lebih terbuka atau lebih apa adanya juga dapat dipahami sebagai bentuk kelekatan (attachment) pada rumah, terutama dimensi person (Scannell \& Gifford, 2010). Menurut Scannell dan Gifford (2010), pemaknaan mengenai realisasi diri tersebut muncul karena mahasiswa memiliki ingatan-ingatan atau pengalaman pribadi yang sangat berkesan. Pengalaman atau ingatan tersebut berhubungan erat dengan proses realisasi diri. Berdasarkan hal tersebut, ia pun memaknai rumah sebagai realisasi dirinya.

Penelitian-penelitian lain menjelaskan bahwa rumah sebagai tempat untuk apa-adanya karena adanya tuntutan dari lingkungan baru, agar mahasiswa dapat beradaptasi dengan budaya dan tuntutan masyarakat setempat (Thurber \& Walton, 2012). Mahasiswa beradaptasi sebagai upaya untuk berafiliasi dengan kelompok tertentu di lingkungan yang baru (Hendrickson, Rosen, \& Aune, 2011). Hal itu yang mungkin membuat mahasiswa merasa dirinya terkekang atau terbebani (Dyson \& Renk, 2006; Sun, 2015), yang memunculkan pemaknaan bahwa rumah adalah sumber tempat yang nyaman dan aman, dan mereka bisa lebih terbuka dengan diri mereka.

Rumah juga dimaknai sebagai keluarga, yang ditunjukkan dengan pernyataan partisipan "karena makna rumah itu bukan cuma tempat tinggal, tapi orang-orang di dalamnya. Jadi gapapa aku ga pulang, tapi aku bisa ketemu sama mama, papa, adek, kakak" (I20). Pemaknaan rumah sebagai orang dapat terbentuk karena adanya interaksi di dalam rumah tersebut (Blumer, 1986; Scannell \& Gifford, 2010; Scharp dkk.,, 2015). Merefleksikan hal ini, salah satu partisipan mengatakan "Kalau malam biasanya nonton, aku sama mama kan suka film korea, jadi nonton bareng di ruang tv. Terus kalo makan kadang kalau memang semuanya di rumah makan bareng tapi sambil nonton" (CT14). Interaksi tersebut yang kemudian memunculkan ikatan antara satu sama lain dan membuat individu merasa selalu ingin dekat dengan orang-orang yang bermakna baginya (Ainsworth dkk., 1978; Bowlby, 1982).

Adanya interaksi aktif dan ikatan sosial yang dimiliki mahasiswa dengan individu di dalam rumahnya juga dapat memunculkan attachment dengan rumah tersebut. Hal ini dapat dijelaskan melalui dimensi place dari teori place attachment, serta dimensi person, yang menggambarkan betapa berharganya rumah bagi individu karena rumah memberikan pengalaman pribadi bersama keluarga (Scannell \& Gifford, 2013). Hal ini memungkinkan mahasiswa memaknai rumah bukan hanya sebagai kumpulan orang yang bermakna baginya, namun juga sebagai tempat dimana interaksi yang menyenangkan dengan orangorang tersebut dapat terjadi. Makna tersebut ditunjukkan dengan pernyataan partisipan, seperti "Terus disana juga, tempat keluarga berkumpul. Jadi kayak senang aja gitu. Itu adalah tempat yang membuat aku bahagia gitu" (DA34). Rumah yang dimaknai sebagai orang dan tempat orang-orang tersebut berkumpul juga dapat terjadi karena adanya hubungan positif di dalam keluarga, yang menjadi sumber dukungan ketika sedang mengalami masa-masa sulit (Coward, 2018). Pengalaman tersebut ditunjukkan dengan pernyataan "Ya aku merasa, karena di rumah 
ada orang tua, terus ada adik juga. Terus, di rumah juga aku bisa kayak berinteraksi dengan mereka dan me-recharge energiku lagi." (AS20).

Penelitian ini tentunya belum sempurna, yang mengandung beberapa keterbatasan. Keterbatasan pertama berkaitan dengan fokus penelitian hanya pada mahasiswa rantau. Fokus ini didasarkan pada asumsi bahwa mahasiswa rantau akan cenderung lebih sering mengalami perasaan rindu rumah. Meskipun demikian, masih ada kemungkinan mahasiswa yang pulang juga mengalami perasaan rindu rumah. Keterbatasan kedua berkaitan dengan asumsi penelitian ini bahwa perasaan rindu rumah atau homesickness hanya terdiri dari satu pencetus, yakni adanya kelekatan yang kuat dengan rumah. Meskipun demikian, terdapat teori lain yang menyatakan bahwa perasaan rindu rumah bisa juga diakibatkan oleh adanya kesulitan dan kegagalan dalam beradaptasi (Stroebe dkk., 2016).

Untuk studi lanjutan, peneliti mengajukan beberapa saran. Pertama adalah mengkaji berbagai strategi yang dilakukan oleh mahasiswa rantau untuk mengatasi perasaan homesickness. Kedua adalah mengikutsertakan mahasiswa dengan jarak geografis yang tidak terlalu jauh antara rumah dengan tempat merantau. Tujuannya adalah untuk memahami pemaknaan rumah yang terbentuk pada mahasiswa yang memiliki akses lebih mudah untuk pulang ke rumah karena terdapat perbedaan pada dimensi dari homesickness pada mahasiswa dengan jarak geografis yang berbeda (Stroebe, Van Vliet, Hewstone, \& Willis, 2002). Ketiga adalah mengeksplorasi proses adaptasi dengan lingkungan baru di perantauan, apa yang dirasakan, dan hal-hal apa yang membuat proses adaptasi tersebut terasa sulit. Keempat adalah menjelaskan fenomena homesickness dengan pendekatan budaya mahasiswa, untuk mengetahui pengaruh dari kebudayaan dan memberikan intervensi yang lebih tepat (Stroebe dkk., 2002).
Selain saran untuk studi lanjutan, peneliti juga mengajukan beberapa saran praktis. Pertama, perlu adanya lingkungan yang suportif dan interaktif bagi mahasiswa, yang bisa mendorong mahasiswa untuk bisa saling mengenal dan merasakan kenyamanan (Cave, 1997; Scharp dkk., 2015). Lingkungan yang suportif bisa ditumbuhkan melalui, misalnya, apresiasi yang tulus oleh dosen kepada setiap individu ketika sudah menyelesaikan aktivitas di perkuliahan. Kedua, intervensi yang dapat dilakukan oleh psikolog dan konselor adalah membantu mahasiswa mencari dan menemukan berbagai hal yang mampu memenuhi ekspektasi mereka (pemaknaan mengenai "rumah") agar perasaan rindu rumah (homesickness) dapat berkurang (Russo-Netzer, Schulenberg, \& Batthyany, 2016; Scharp dkk., 2015). Ketiga, ketika mahasiswa dan psikolog atau konselor telah memahami hal yang dirindukan dari rumah dan makna rumah, mahasiswa dapat diminta untuk memvisualisasikan dalam pikirannya mengenai hal yang dirindukan. Visualisasi mampu membantu mahasiswa untuk merasa lebih bahagia dan meningkatkan selfesteem (Scannell \& Gifford, 2016).

\section{Daftar Pustaka}

Adit, A. (2020, Januari 27). Daftar 95 perguruan tinggi terakreditasi A Indonesia. Kompas. Diambil dari https://edukasi.kompas.com/read/2020/01 /27/13081761/daftar-95-perguruan-tinggiterakreditasi-a-indonesia

Ainsworth, M. D., Blehar, M., Waters, E., \& Wall, S. (1978). Patterns of attachment: A psychological study of the strange situation. New York: Erlbaum.

American Psychiatric Association. (2013). Diagnostic and statistical manual of mental disorder (DSM-5). In American Psychiatric Association (5th ed.). American Psychiatric Association. https://doi.org/10.1192/bjp.111.479.1009-a Mahasiswa asal Riau terbanyak kedua di Yogyakarta. (2014, September 20). 
AntaraRiau.Com.

Diakses

dari

https://riau.antaranews.com/berita/42711/ mahasiswa-asal-riau-terbanyak-kedua-diyogyakarta

Archer, J., Ireland, J., Amos, S., Board, H., \& Currid, L. (1998). Derivation of a homesickness scale. British Journal of Psychology, 89, 205-221. http://dx.doi.org/10.1111/j.20448295.1998.tb02681.x

Azizi, S. (2015). Relationship between homesickness and test anxiety in nonnative students of Shiraz University of Medical Sciences International Branch in the clinical and physiopathology course in 2013. Global Journal of Health Science, $8(7)$, 293-300. https://doi.org/10.5539/gjhs.v8n7p293

Blumer, H. (1986). Symbolic interactionism: Perspective and method. USA: University of California Press.

Bowlby, J. (1982). Attachment and loss: Attachment (2nd ed., Vol. 1). New York, USA: Basic Books.

Braun, V., \& Clarke, V. (2006). Using thematic analysis in psychology. Qualitative Research in Psychology,3(2), 77-101. https://doi.org/10.1057/978-1-137-35913-1

Cave, C. B. (1997). Very long-lasting priming in picture naming. Psychological Science, 8 , 322-325.

https://doi.org/10.1111\%2Fj.1467-

9280.1997.tb00446.x

Compton, W. C., \& Hoffman, E. (2013). Positive psychology the science of happiness and flourishing (2nd ed.). Belmont, CA, USA: Wadsworth Publishing.

Coward, S. (2018). Home life: The meaning of home for people who have experienced homelessness (Doctoral dissertation, University of Sheffiled, United Kingdom). Diakses dari http://etheses.whiterose.ac.uk/21626/

Creswell, J. W., \& Creswell, J. D. (2018). Research design: Qualitative, quantitative, and mixed method approaches (5th ed.). UK: Sage Publication, Inc. https://doi.org/10.1017/CBO97811074153 24.004

Creswell, J. W., \& Poth, C. N. (2018). Qualitative inquiry and research design: Choosing among five approaches (4th ed.). UK: Sage Publication, Inc.

Dunn, W. W. (2000). Habit: What's the brain got to do with it?. The Occupational Therapy Journal of Research, 20(55), 608620. https://doi.org/10.5014/ajot.55.6.608

Dyson, R., \& Renk, K. (2006). Freshmen adaptation to university life: Depressive symptoms, stress, and coping. Journal of Clinical Psychology, 62(10), 1231-1244. https://doi.org/10.1002/jclp.20295

Feist, J., \& Feist, G. J. (2009). Theories of personality. Boston, MA: McGraw Hill Higher Education.

Fidzani, L. C., \& Read, M. A. (2012). Bedroom personalization by urban adolescents in Botswana: Developing place attachment. Children Youth and Environments, 22(2), 66-92.

https://doi.org/10.7721/chilyoutenvi.22.2.0 066

Hawkins, R. D., \& Williams, J. M. (2017). Childhood attachment to pets: Associations between pet attachment, attitudes to animals, compassion, and humane behaviour. International Journal of Environmental Research and Public Health, $14(5)$. 490. https://doi.org/10.3390/ijerph14050490

Hendrickson, B., Rosen, D., \& Aune, R. K. (2011). An analysis of friendship networks, social connectedness, homesickness, and satisfaction levels of international students. International Journal of Intercultural Relations, 35(3), 281-295. https://doi.org/10.1016/j.ijintrel.2010.08.0 01

Istanto, T. L., \& Engry, A. (2019). Hubungan antara dukungan sosial dan homesickness 
pada mahasiswa rantau yang berasal dari luar pulau Jawa di Universitas Katolik Widya Mandala Surabaya Kampus Pakuwon City. Jurnal Experientia, 7, 19$30 . \quad$ Diakses dari https://pdfs.semanticscholar.org/714d/26af b10174c9c768a538606cc30dff465dc8.pdf

Johnson, M. K., Kim, J. K., \& Risse, G. (1985).

Do alcoholic Korsakoff's syndrome patients acquire affective reactions? Journal of Experimental Psychology: Learning, Memory, and Cognition, 11(1), 22-36. https://doi.org/10.1037/02787393.11.1.22

Menristekdikti umumkan klasterisasi perguruan tinggi Indonesia 2019, fokuskan hasil dari perguruan tinggi. (2019, Agustus 16). Ristekdikti.go.id. Diakses 29 November 2020 dari https://ldikti12.ristekdikti.go.id/2019/08/1 7/menristekdikti-umumkan-klasterisasiperguruan-tinggi-indonesia-2019fokuskan-hasil-dari-perguruan-tinggi.html Lincoln S. (2015) 'My bedroom is me': Young people, private space, consumption and the family home. In E. Casey \& Y. Taylor (Eds.), Intimacies, critical consumption and diverse economies (pp 87-106). London, UK: Palgrave Macmillan. https://doi.org/10.1057/9781137429087_ 5

Lingga, R. W. W. L., \& Tuapattinaja, J. M. R. (2012). Gambaran virtue mahasiswa perantau. Predicara, 1(2), 59-68. Diakses dari

https://jurnal.usu.ac.id/index.php/predicara /article/view/533/308

Lumawo, F. (2007). Gambaran homesickness dan identifikasi tipe attachment pada mahasiswa indonesia yang menjalankan studi di luar negeri (Skripsi, Universitas Katolik Indonesia Atma Jaya, Jakarta, Indonesia). Diakses dari https://lib.atmajaya.ac.id/default.aspx?tabI $\mathrm{D}=61 \& \mathrm{src}=\mathrm{k} \& \mathrm{id}=146075$
Nijhof, K. S., \& Engels, R. C. M. E. (2007). Parenting styles, coping strategies, and the expression of homesickness. Journal of Adolescence, 30(5), 709-720. https://doi.org/10.1016/j.adolescence. 2006. 11.009

Pina-Concas, M., Catamo, E., Biino, G., Tonioli, D., Gasparini, P., \& Robino, A. (2019). Factors associated with food liking and their relationship with metabolic traits in Italian Cohorts. Food Quality and Preference, 75, 64-70. https://doi.org/doi:10.1016/j.foodqual.201 9.02.010

Poyrazli, S., \& Lopez, M. D. (2007). An exploratory study of perceived discrimination and homesickness: A comparison of international students and American students. Journal of Psychology: Interdisciplinary and Applied, 141(3), 263-280.

https://doi.org/10.3200/JRLP.141.3.263280

Robinson, O. C. (2014). Sampling in interviewbased qualitative research: A theoretical and practical guide. Qualitative Research in Psychology, 11(1), 25-41. https://doi.org/10.1080/14780887.2013.80 1543

Russo-Netzer, P., Schulenberg, S. E., \& Batthyany, A. (2016). Clinical perspectives on meaning: Understanding, coping and thriving through science and practice. In P. Russo-Netzer, S. E. Schulenberg, \& A. Batthyany (Eds.), Clinical perspectives on meaning: Positive and existential psychotherapy ( $\mathrm{p}$. 1-13). Springer International Publishing. https://doi.org/10.1007/978-3319-41397-6_1

Santrock, J. W. (2016). Adolescence (16th ed.). USA: Mc Graw Hill Education.

Santrock, J. W. (2020). A topical approach to life-span development $\left(10^{\text {th }}\right.$ ed.). USA: Mc Graw Hill.

Scannell, L., \& Gifford, R. (2010). Defining 
place attachment: A tripartite organizing framework. Journal of Environmental Psychology, 30(1), 1-10. https://doi.org/10.1016/j.jenvp.2009.09.00 6

Scannel, L., \& Gifford, R. (2013). Comparing theories of interpersonal and place attachment. In L. C. Manzo \& P. DevineWright (Eds.), Place attachment: Advances in theory, methods, and application (pp. 23-36). UK: Routledge.

Scannell, L., \& Gifford, R. (2016). Place attachment enhances psychological need satisfaction. Environment and Behavior, 49(4), 359-389. https://doi.org/10.1177/001391651663764 8

Scharp, K. M., Paxman, C. G., \& Thomas, L. J. (2015). "I Want to go home": Homesickness experiences and socialsupport-seeking practices. Environment and Behavior, 48(9), 1175-1197. https://doi.org/10.1177/001391651559047 5

Shaver, P. R., \& Mikulincer, M. (2007). Attachment theory and research: Core concepts, basic principles, conceptual bridges. In A. Kruglanski \& E. T. Higgins (Eds.), Social psychology: Handbook of basic principles (pp. 650-677). New York: Guilford Press.

Stroebe, M., Schut, H., \& Nauta, M. (2015). Homesickness: A systematic review of the scientific literature. Review of General Psychology, 19(2), 157-171. https://doi.org/10.1037\%2Fgpr0000037

Stroebe, M., Schut, H., \& Nauta, M. H. (2016). Is homesickness a mini-grief? Development of a dual process model. Clinical Psychological Science, 4(2), 344 358.

https://doi.org/10.1177/216770261558530 2

Stroebe, M., Van Vliet, T., Hewstone, M., \& Willis, H. (2002). Homesickness among students in two cultures: Antecedents and consequences.

British

Journal of

Psychology, 93(2),

147-168.

https://doi.org/10.1348/000712602162508

Sun, J. (2015). Homesick at college: A predictive model for first-year first-time students (Dissertation, Iowa State University, USA). Diakses dari from http://lib.dr.iastate.edu/etd/14890

Thurber, C. A., Walton, E., Murray, R. D., Frankowski, B. L., Gereige, R. S., Mears, C. J., Roland, M. M., Young, T. L., Grant, L. M., Hyman, D., Magalnick, H., Monteverdi, G. J., Pattishall, E. G., LaCursia, N., Mazyck, D., Vernon-Smiley, M., Wallace, R., \& Li, S. (2007). Preventing and treating homesickness. Pediatrics, 119(1), 192-201. https://doi.org/10.1542/peds.2006-2781

Thurber, C. A., \& Walton, E. A. (2012). Homesickness and adjustment in university students. Journal of American College Health, 60(5), 415-419. https://doi.org/10.1080/07448481.2012.67 3520

Statistik Universitas Padjadjaran September 2016. (2016). Unpad.ac.id. Diakses 20 November 2020 dari http://www.unpad.ac.id/wpcontent/uploads/2015/05/Unpad-DalamAngka-2016.pdf

Vingerhoets, A. J. J. M. (2005). The Homesickness concept: Questions and doubts. In M. A. L. Van-Tilburg \& A. J. J. M. Vingerhoets (Eds.), Psychological aspects of geographical moves: Homesickness and acculturation stress. Netherlands: Tilburg University Press.

Wądołowska, L., Babicz-Zielińska, E., \& Czarnocińskac, J. (2008). Food choice models and their relation with food preferences and eating frequency in the Polish population: POFPRES study. Food Policy (33), 122-134. https://doi.org/10.1016/j.foodpol.20 